\title{
Ocular dimensions and the heredity of open-angle glaucoma
}

\author{
A. TOMLINSON AND D. A. LEIGHTON \\ Department of Ophthalmology, University of Manchester
}

It has long been recognized that heredity plays a part in the aetiology of glaucoma. In open-angle glaucoma an autosomal recessive inheritance has been suggested (Waardenburg, I949), but in the majority of families reported in which a high prevalence has been found, an autosomal dominant transmission seems apparent (Miller and Paterson, i 962; François, Heintz-de Bree, and Tripathi, ı 966; François and Heintz-de Bree, I 966 ; François, I966). The penetrance of the dominant gene appears, however, to be highly variable; François and Heintz-de Bree ( 1966 ) noted a 98 per cent. penetrance in some families but admitted that in many others the penetrance was very low. On the other hand, Armaly, Monstavicius, and Sayegh (1968) suggested a multifactorial aetiology for the condition. A similar controversy exists in regard to the aetiology of angle-closure glaucoma.

The influence of ocular dimensions in the aetiology of angle-closure glaucoma is well established (Priestley-Smith, I883; Rosengren, I950; Törnquist, I956; Lowe, I970; Storey and Phillips, I97 I). Tomlinson and Leighton (1973) have considered the role of ocular dimensions in the heredity of angle-closure glaucoma in an attempt to define the importance of individual dimensions in the aetiology and heredity of the condition. Their results, which may favour a multifactorial determination, were discussed in the light of conflicting views concerning the heredity of that form of glaucoma.

The influence of ocular dimensions on the aetiology of open-angle glaucoma is apparently not as great as it is in angle-closure glaucoma, but there is some evidence to show that the myopic eye may be particularly sensitive to raised intraocular pressure. Perkins and Jay (1960) reported that 22 per cent. of 205 patients with open-angle glaucoma over the age of 50 years were myopic; under the age of 50 the incidence of myopia was 37.8 per cent. A high incidence of open-angle glaucoma in myopic patients has been observed by Weekers, Lavergne, and Prijot (1958) and by Diaz-Dominguez (196 I, 1966). A relationship between myopia and a high response of ocular tension to topical corticosteroids also appears to exist (Podos, Becker, and Morton, I966). Törnquist and Brodén (1958) and Tomlinson and Leighton (1972) have observed that eyes with open-angle glaucoma have significantly shallower anterior chambers than normal eyes. This may be a contributory factor to the development of open-angle glaucoma, as François, Rabaey, Neetens, and Evens (1958) found the reduction in anterior chamber depth to have more effect on the outflow of aqueous humour from the eye than any other factor considered.

An investigation was carried out in which certain ocular dimensions were measured in patients with open-angle glaucoma and in their first-degree relatives. A similarity in these dimensions between the patients and relatives may explain an increased liability to the 
condition in these relatives, and conversely any dissimiliarities may explain why many relatives remain unaffected, thus clarifying the role of ocular dimensions in the aetiology of open-angle glaucoma.

\section{Methods}

SUBJECTS

There were Ioo in all. These comprised:

(I) 16 patients with open-angle glaucoma.

(2) 19 siblings of patients with open-angle glaucoma.

(3) 2 I offspring of patients with open-angle glaucoma.

(4) 44 normal controls.

Each subject in categories (1), (2), and (3) was matched for sex, age, and refractive error with a control subject (4) within the age range + Io to - Io years and to within one dioptre of the best sphere refraction. Some control subjects were used more than once, i.e. they were matched with a subject from categories (I), (2), and (3); this accounts for the smaller number of normal controls (44) than the total number in the other three categories combined $(56)$.

\section{( I) Index patients with open-angle glaucoma}

The dimensions from one eye of sixteen patients with open-angle glaucoma* were analysed statistically ( 6 right, io left). If both eyes were affected the eye to be measured was chosen at random by the toss of a coin; if only one eye was affected the data from this eye were used in the statistical analysis. The ages of the patients ranged from $3^{8}$ to 88 years; eight were male and eight female. Their refractions ranged from $+8 \cdot 5$ to $-9 \cdot 0 \mathrm{D}$ sph. None had had a drainage operation in the eye which was included for analysis. Three patients had been treated with Tosmilen drops o 06 per cent., but this was discontinued 2 weeks before examination, and five had been treated with pilocarpine (2 or 4 per cent.) which was discontinued 48 hours before examination. Wilkie, Drance, and Schulzer (1969) have shown a reduction in the depth of the anterior chamber under the influence of miotics. All patients in this group had at least one relative (sibling or offspring) who was also included in this survey.

\section{(2) Siblings of patients with open-angle glaucoma}

The dimensions from one eye, chosen at random (9 right, ro left), of nineteen siblings of patients with open-angle glaucoma were analysed. Twelve were related to patients in Group I. The siblings' ages ranged from 18 to 72 years; seven were male and twelve female. Their refractions ranged from $+6 \cdot 25$ to $-4 \cdot 75 \mathrm{D}$ sph.

\section{(3) Offspring of patients with open-angle glaucoma}

The dimensions from one eye, chosen at random (9 right, 12 left) of 2 I offspring of patients with open-angle glaucoma were analysed. Twelve were related to patients in Group I. The offspring were aged between 22 and 62 years; thirteen were male and eight female. Their refractions ranged from +4.75 to $-4.0 \mathrm{D}$ sph.

\section{(4) “Normal" control subjects}

There were 44 controls ( 23 male and 2 I female). Their ages ranged from 19 to 83 years and their refractions from $+7 \cdot 5$ to $-9 \cdot 0 \mathrm{D}$. sph. They had clinically normal eyes with no evidence of glaucoma, and they had no family history of the condition. In each of the 44 controls, the dimensions were recorded from one eye only chosen at random by the toss of a coin (23 right, 2 I left).

*All had at least one affected eye with pathological cupping of the optic disc, raised intraocular pressure (over $23 \mathrm{~mm}$. $\mathrm{Hg}$ ) on many occasions, and defects in the visual field of a type found in glaucoma 
OCULAR DIMENSIONS

The following were recorded on each subject by the methods indicated:

(i) Refraction determined objectively and subjectively

(ii) Mean central corneal curvature, i.e. $\frac{\text { (horizontal }+ \text { vertical radius) }}{2}$, by Zeiss keratometry

(iii) Horizontal corneal diameter from a colour photograph of the anterior surface of the eye

(iv) Central corneal thickness by the Type I attachment for the Haag-Streit goo slit lamp

(v) Depth of the anterior chamber measured from the anterior surface of the cornea to the anterior surface of the lens with the Type II attachment for the Haag-Streit goo slit lamp

(vi) Applanation tension recorded with the attachment for the Haag-Streit goo slit lamp

(vii) Thickness of the crystalline lens from an antero-posterior axis trace of the eye obtained

(viii) Length of the vitreous body $\int$ by A-Scan ultrasonography

(ix) Axial length of the eyeball - found from the addition of (v), (vii), and (viii)

(x) The relative lens position was calculated from the formula:

$$
\text { relative lens position }=: \frac{\text { anterior chamber depth }+\frac{1}{2} \text { lens thickness }}{\text { axial length }}
$$

(see Lowe, 1970)

(xi) The corneal height was calculated from the formula:

$$
\text { height }=\text { corneal radius }-\sqrt{(\text { corneal radius })^{2}-\frac{(\text { corneal diameter })^{2}}{4}}
$$

(see Delmarcelle, Collignon-Brach, and Luyckx-Bacus, 1969)

(xii) The axial length of the scleral envelope was found by subtracting the corneal height from axial length (see Storey and Phillips, 197I)

\section{Results}

The Wilcoxon matched-pairs signed-ranks test (Siegel, 1956) was used to analyse the data. This test was particularly appropriate because each index patient, sibling, or offspring had been paired, by matching for age, sex, and refractive error, with a control subject.

The comparisons between the dimensions for the open-angle glaucoma patients or relatives with the control subjects will be considered in three separate sections, I, II, and III. The mean values found for each dimension in the index, sibling, offspring, and control subject are shown in Tables I to III, together with the results of the statistical test and level of significance of the differences found between the samples. In Section IV a comparison is made between affected and unaffected members of the same sibship.

\section{Ocular dimensions of patients with open-angle glaucoma compared with those of normal control subjects}

The results are shown in Table I. The depth of the anterior chamber in open-angle glaucoma was found to be significantly shallower $(\mathrm{P}<0 \cdot 02)$ than in the normal, and the lens thickness significantly greater $(\mathrm{P}=0 \cdot 05)$. Ocular tension was of course greater in the glaucoma patients than in the control subjects $(\mathrm{P}<\mathrm{O} \cdot \mathrm{OOI})$. 
Table I Group of sixteen open-angle glaucoma index patients compared with sixteen normal subjects of similar age, sex, and refractive error by a Wilcoxon Matched-Pairs Signed-Ranks test

\begin{tabular}{|c|c|c|c|c|c|c|c|c|c|c|c|c|}
\hline \multirow[b]{3}{*}{ Samples } & \multicolumn{11}{|c|}{ Ocular dimensions (means) } & \multirow[b]{3}{*}{$\begin{array}{l}\text { Mean } \\
\text { age } \\
(y r s)\end{array}$} \\
\hline & \multicolumn{4}{|l|}{ Corneal } & \multirow[b]{2}{*}{$\begin{array}{l}\text { Anterior } \\
\text { chamber } \\
\text { depth } \\
(\mathrm{mm} .)\end{array}$} & \multirow[b]{2}{*}{$\begin{array}{l}\text { Lens } \\
\text { thick- } \\
\text { ness } \\
(\mathrm{mm} .)\end{array}$} & \multirow[b]{2}{*}{$\begin{array}{l}\text { Relative } \\
\text { lens } \\
\text { position }\end{array}$} & \multirow[b]{2}{*}{$\begin{array}{l}\text { Vitreous } \\
\text { length } \\
(\mathrm{mm} .)\end{array}$} & \multirow[b]{2}{*}{$\begin{array}{c}\text { Axial } \\
\text { length } \\
(m m .)\end{array}$} & \multirow[b]{2}{*}{$\begin{array}{l}\text { Length } \\
\text { of } \\
\text { scleral } \\
\text { envolope } \\
(\mathrm{mm} .)\end{array}$} & \multirow[b]{2}{*}{$\begin{array}{l}\text { Applana- } \\
\text { tion } \\
\text { tension } \\
(\mathrm{mm} . \mathrm{Hg})\end{array}$} & \\
\hline & $\begin{array}{l}\text { Radius } \\
(\mathrm{mm} .)\end{array}$ & $\begin{array}{l}\text { Thick- } \\
\text { ness } \\
(\mathrm{mm} .)\end{array}$ & $\begin{array}{l}\text { Diameter } \\
\text { (hori- } \\
\text { zontal) } \\
(\mathrm{mm} .)\end{array}$ & $\begin{array}{l}\text { Height } \\
(\mathrm{mm} .)\end{array}$ & & & & & & & & \\
\hline $\begin{array}{l}\text { Open-angle } \\
\text { glaucoma } \\
\text { index patients }\end{array}$ & $7 \cdot 70$ & 0.565 & I I $\cdot 05$ & $2 \cdot 340$ & $3.12^{*}$ & $4 \cdot 67^{*}$ & $0 \cdot 228$ & $15 \cdot 86$ & $23 \cdot 68$ & $21 \cdot 34$ & $33 \cdot 04^{*}$ & $62 \cdot 25$ \\
\hline $\begin{array}{l}\text { No of matched pairs } \dagger \\
\text { Value of T } \\
\text { Level of significance }\end{array}$ & $\begin{array}{l}16 \\
67.5 \\
<0.50\end{array}$ & $\begin{array}{l}16 \\
36 \cdot 5 \\
<0 \cdot 30\end{array}$ & $\begin{array}{l}15 \\
50 \\
<0.50\end{array}$ & $\begin{array}{l}16 \\
65 \\
<0.50\end{array}$ & $\begin{array}{l}16 \\
23 \cdot 5 \\
<0 \cdot 02\end{array}$ & $\begin{array}{l}16 \\
30 \\
=0 \cdot 05\end{array}$ & $\begin{array}{l}16 \\
38.5 \\
<0.15\end{array}$ & $\begin{array}{l}16 \\
67 \\
<0.50\end{array}$ & $\begin{array}{l}14 \\
48 \\
<0.50\end{array}$ & $\begin{array}{l}16 \\
66 \\
<0.50\end{array}$ & $\begin{array}{l}\text { I } 6 \\
0 \\
<0.001\end{array}$ & $\begin{array}{l}16 \\
49 \cdot 5 \\
<0 \cdot 30\end{array}$ \\
\hline Normal controls & $7 \cdot 77$ & 0.551 & $11 \cdot 20$ & $2 \cdot 248$ & $3 \cdot 40^{*}$ & $4.42^{*}$ & $0 \cdot 237$ & $15 \cdot 90$ & $23 \cdot 74$ & $2 I \cdot 4 I$ & $\overline{15 \cdot 19^{*}}$ & $60 \cdot 63$ \\
\hline
\end{tabular}

* Significant difference between the groups compared. The minimum level of significance acceptable in this study is 5 per cent.

+ For some dimensions pairings were excluded when a tie had occurred in the data between each member of the matched pair (Siegel, r 956 )

II Ocular dimensions of siblings of patients with open-angle glaucoma compared with those of normal control subjects

The results can be seen in Table II. As in the index patients, the anterior chamber depth of the open-angle glaucoma siblings was significantly shallower than in the normal $(\mathrm{P}<$ $0 \cdot 05)$ and the lens thickness significantly greater $(\mathrm{P}<0 \cdot 0 \mathrm{I})$.

Table II Group of nineteen open-angle glaucoma siblings compared with nineteen normal subjects of similar age, sex and refractive error, by a Wilcoxon Matched-Pairs Signed-Ranks test

\begin{tabular}{|c|c|c|c|c|c|c|c|c|c|c|c|c|}
\hline \multirow{3}{*}{ Samples } & \multicolumn{11}{|c|}{ Ocular dimensions (means) } & \multirow{3}{*}{$\begin{array}{l}\text { Mean } \\
\text { age } \\
\text { (yrs) }\end{array}$} \\
\hline & \multicolumn{4}{|l|}{ Cornea } & \multirow{2}{*}{$\begin{array}{l}\text { Anterior } \\
\text { chamber } \\
\text { depth } \\
(\mathrm{mm} .)\end{array}$} & \multirow{2}{*}{$\begin{array}{l}\text { Lens } \\
\text { thick- } \\
\text { ness } \\
\text { (mm.) }\end{array}$} & \multirow{2}{*}{$\begin{array}{l}\text { Relative } \\
\text { lens } \\
\text { position }\end{array}$} & \multirow{2}{*}{$\begin{array}{l}\text { Vitreous } \\
\text { length } \\
(\mathrm{mm} .)\end{array}$} & \multirow{2}{*}{$\begin{array}{c}\text { Axial } \\
\text { length } \\
(\mathrm{mm} .)\end{array}$} & \multirow{2}{*}{$\begin{array}{l}\text { Length } \\
\text { of } \\
\text { scleral } \\
\text { envelope } \\
(\mathrm{mm} .)\end{array}$} & \multirow{2}{*}{$\begin{array}{l}\text { Applana- } \\
\text { tion } \\
\text { tension } \\
(\mathrm{mm} . \mathrm{Hg})\end{array}$} & \\
\hline & $\begin{array}{l}\text { Radius } \\
(\mathrm{mm} .)\end{array}$ & $\begin{array}{l}\text { Thick- } \\
\text { ness } \\
(m m .)\end{array}$ & $\begin{array}{l}\text { Diameter } \\
(\mathrm{mm} .)\end{array}$ & $\begin{array}{l}\text { Height } \\
(\mathrm{mm} .)\end{array}$ & & & & & & & & \\
\hline $\begin{array}{l}\text { Open-angle } \\
\text { glaucoma siblings }\end{array}$ & $7 \cdot 56$ & 0.577 & I0·96 & $2 \cdot 416$ & $3.09^{*}$ & $4 \cdot 6 o^{*}$ & $0 \cdot 235$ & $15 \cdot 29$ & $23 \cdot 00$ & $20 \cdot 64$ & $16 \cdot 95$ & $54 \cdot 42$ \\
\hline $\begin{array}{l}\text { No of matched pairs } \dagger \\
\text { Value of } T \\
\text { Level of significance }\end{array}$ & $\begin{array}{l}19 \\
68 \\
<0.40\end{array}$ & $\begin{array}{l}17 \\
42 \\
<0 \cdot 20\end{array}$ & $\begin{array}{l}18 \\
66 \\
<0.50\end{array}$ & $\begin{array}{l}19 \\
88 \\
<0 \cdot 50\end{array}$ & $\begin{array}{l}19 \\
39 \\
<0 \cdot 05\end{array}$ & $\begin{array}{l}\mathrm{I} 8 \\
28 \\
<0 \cdot 01\end{array}$ & $\begin{array}{l}18 \\
73 \\
<0 \cdot 50\end{array}$ & $\begin{array}{l}19 \\
61 \\
<0.40\end{array}$ & $\begin{array}{l}19 \\
71 \\
<0.50\end{array}$ & $\begin{array}{l}19 \\
72 \\
<0.50\end{array}$ & $\begin{array}{l}14 \\
23.5 \\
<0.07\end{array}$ & $\begin{array}{l}19 \\
60.5 \\
<0.40\end{array}$ \\
\hline Normal controls & $7 \cdot 66$ & 0.564 & II $\cdot 08$ & $2 \cdot 269$ & $3.33^{*}$ & $4 \cdot 39^{*}$ & $0 \cdot 237$ & $15 \cdot 69$ & $23 \cdot 40$ & $2 \mathrm{I} \cdot 02$ & 15.05 & $53 \cdot 11$ \\
\hline
\end{tabular}

Footnotes as in Table I

III Ocular dimensions of offspring of patients with open-angle glaucoma compared with those of normal control subjects

The results of this comparison are shown in Table III. The only deviation from the normal in these offspring was for corneal diameter, which wassignificantly smaller $\left(\mathrm{P}<0^{\cdot 05}\right)$.

IV Ocular dimensions of index patients compared directly with those of their unaffected siblings

A comparison was made between eight index patients and their unaffected siblings. Unfortunately, although satisfactory matching was achieved for age and refractive error, this was not possible for sex; four pairs were correctly matched, but two male index patients were matched with two female unaffected siblings, and two female index patients were matched with two male unaffected siblings. At least for these four pairings sex differences might have tended to cancel themselves out. 
Table III Group of 2 I open-angle glaucoma offspring compared with 2 I normal subjects of age, sex, and refractive error by a Wilcoxon Matched-Pairs Signed-Ranks test

\begin{tabular}{|c|c|c|c|c|c|c|c|c|c|c|c|}
\hline \multirow{3}{*}{ Samples } & \multicolumn{11}{|c|}{ Ocular dimensions (means) } \\
\hline & \multicolumn{4}{|l|}{ Cornea } & \multirow{2}{*}{$\begin{array}{l}\text { Anterior } \\
\text { chamber } \\
\text { depth } \\
(\mathrm{mm} .)\end{array}$} & \multirow{2}{*}{$\begin{array}{l}\text { Lens } \\
\text { thick- } \\
\text { ness } \\
(\mathrm{mm} .)\end{array}$} & \multirow{2}{*}{$\begin{array}{l}\text { Relative } \\
\text { lens } \\
\text { position }\end{array}$} & \multirow{2}{*}{$\begin{array}{l}\text { Vitreous } \\
\text { length } \\
(\mathrm{mm} .)\end{array}$} & \multirow{2}{*}{$\begin{array}{l}\text { Axial } \\
\text { length } \\
(\mathrm{mm} .)\end{array}$} & \multirow{2}{*}{$\begin{array}{l}\text { Length } \\
\text { of } \\
\text { scleral } \\
\text { envelope } \\
(\mathrm{mm} .)\end{array}$} & \multirow{2}{*}{$\begin{array}{l}\text { Applana- } \\
\text { tion } \\
\text { tension } \\
(\mathrm{mm} . \\
\mathrm{Hg})\end{array}$} \\
\hline & $\begin{array}{l}\text { Radius } \\
(\mathrm{mm} .)\end{array}$ & $\begin{array}{l}\text { Thick- } \\
\text { ness } \\
(\mathrm{mm} .)\end{array}$ & $\begin{array}{l}\text { Diameter } \\
(\mathrm{mm} .)\end{array}$ & $\begin{array}{l}\text { Height } \\
\text { (mm.) }\end{array}$ & & & & & & & \\
\hline $\begin{array}{l}\text { Open-angle } \\
\text { glaucoma offspring }\end{array}$ & $7 \cdot 79$ & $0 \cdot 565$ & $1 \mathrm{I} \cdot 14^{*}$ & $2 \cdot 36 I$ & $3 \cdot 31$ & $4 \cdot 24$ & 0.235 & 15.50 & $23 \cdot 14$ & $20 \cdot 77$ & 15.57 \\
\hline $\begin{array}{l}\text { No of matched pairs } \dagger \\
\text { Value of T } \\
\text { Level of significance }\end{array}$ & $\begin{array}{l}20 \\
78 \cdot 5 \\
<0 \cdot 30\end{array}$ & $\begin{array}{l}19 \\
96.5 \\
<0 \cdot 40\end{array}$ & $\begin{array}{l}20 \\
49 \cdot 5 \\
<0.05\end{array}$ & $\begin{array}{l}21 \\
64 \\
<0 \cdot 20\end{array}$ & $\begin{array}{l}2 \mathrm{I} \\
94 \\
<0 \cdot 30\end{array}$ & $\begin{array}{l}21 \\
76 \\
<0 \cdot 20\end{array}$ & $\begin{array}{l}2 \mathrm{I} \\
98 \\
<0 \cdot 40\end{array}$ & $\begin{array}{l}2 \mathrm{I} \\
92.5 \\
<0.40\end{array}$ & $\begin{array}{l}2 \mathrm{I} \\
\text { IOI } \\
<0 \cdot 40\end{array}$ & $\begin{array}{l}2 \mathrm{I} \\
\mathrm{I} 8 \\
<0.50\end{array}$ & $\begin{array}{l}20 \\
94 \\
<0.30\end{array}$ \\
\hline Normal controls & $7 \cdot 84$ & 0.562 & $\overline{11 \cdot 43^{*}}$ & $2 \cdot 478$ & $3 \cdot 38$ & $4 \cdot 10$ & $0 \cdot 235$ & 15.65 & $23 \cdot 15$ & $20 \cdot 67$ & $15 \cdot 29$ \\
\hline
\end{tabular}

Footnotes as in Table I

Ocular tension was of course significantly greater in the index patients than in their unaffected siblings $(\mathrm{P}<0 \cdot 00 \mathrm{I})$. The ratio $\frac{\text { Axial length of eyeball }}{\text { Corneal diameter }}$ was significantly greater in the index patients than in their unaffected siblings $(\mathrm{T}=0 ; \mathrm{P}<0 \cdot 0 \mathrm{I})$. Because of the lack of control of sex, no firm conclusion can be drawn from this, nor from a lack of significant differences in the other dimensions considered (Table IV).

Table IV Ocular dimensions recorded for a group of eight open-angle glaucoma patients each matche his own sibling. The values obtained for the two groups were compared by a Wilcoxon Matched-Pairs Ranks Test; the value of $T$ is shown together with the number of ranked pairs with a sign and the significance of any difference found

\begin{tabular}{|c|c|c|c|c|c|c|c|c|c|c|c|c|}
\hline \multirow{3}{*}{ Samples } & \multicolumn{12}{|c|}{ Ocular dimensions (means) } \\
\hline & \multicolumn{4}{|l|}{ Cornea } & \multirow{2}{*}{$\begin{array}{l}\text { Anterior } \\
\text { chamber } \\
(\text { depth }) \\
(\mathrm{mm} .)\end{array}$} & \multirow{2}{*}{$\begin{array}{l}\text { Lens } \\
\text { thick- } \\
\text { ness } \\
(\mathrm{mm} .)\end{array}$} & \multirow{2}{*}{$\begin{array}{l}\text { Relative } \\
\text { lens } \\
\text { position }\end{array}$} & \multirow{2}{*}{$\begin{array}{l}\text { Vitreous } \\
\text { length } \\
(\mathrm{mm} .)\end{array}$} & \multirow{2}{*}{$\begin{array}{l}\text { Axial } \\
\text { scleral } \\
(\mathrm{mm} .)\end{array}$} & \multirow{2}{*}{$\begin{array}{l}\text { Length } \\
\text { of } \\
\text { scleral } \\
\text { envelope } \\
(m m .)\end{array}$} & \multirow{2}{*}{$\begin{array}{l}\text { Applana- } \\
\text { tion } \\
\text { tension } \\
(\mathrm{mm} . \\
\mathrm{Hg})\end{array}$} & \multirow{2}{*}{$\begin{array}{l}\text { Best } \\
\text { sphere } \\
\text { refraction } \\
\text { (dioptres) }\end{array}$} \\
\hline & $\begin{array}{l}\text { Radius } \\
(\mathrm{mm} .)\end{array}$ & $\begin{array}{l}\text { Thick- } \\
\text { ness } \\
(m m .)\end{array}$ & $\begin{array}{l}\text { Diameter } \\
(\mathrm{mm} .)\end{array}$ & $\begin{array}{l}\text { Height } \\
(\mathrm{mm} .)\end{array}$ & & & & & & & & \\
\hline $\begin{array}{l}\text { Open-angle } \\
\text { glaucoma } \\
\text { index } \\
\text { patients }\end{array}$ & $7 \cdot 70$ & 0.554 & II $\cdot 07$ & $2 \cdot 35$ & $3 \cdot 30$ & $4 \cdot 49$ & $0 \cdot 231$ & $16 \cdot 27$ & $24 \cdot 10$ & $21 \cdot 75$ & $32 \cdot 75^{*}$ & $-1 \cdot 88$ \\
\hline \multirow{3}{*}{$\begin{array}{l}\text { No of } \\
\text { matched } \\
\text { pairs } \dagger \\
\text { Value of } \mathrm{T} \\
\text { Level of } \\
\text { significance }\end{array}$} & 8 & 8 & 8 & 8 & 8 & 8 & 8 & 8 & 8 & 8 & 8 & 6 \\
\hline & 9 & 7 & Io & 8 & 18 & 17 & 6 & 9 & 8 & 5 & o & 5 \\
\hline & $<0.30$ & $<0.20$ & $<0.30$ & $<0.12$ & $<0.50$ & $<0.50$ & $<0.12$ & $<0.30$ & $<0.30$ & $<0.10$ & $<0.00$ I & $<0.25$ \\
\hline $\begin{array}{l}\text { Open-angle } \\
\text { glaucoma } \\
\text { siblings }\end{array}$ & $7 \cdot 58$ & 0.584 & $I I \cdot I 6$ & $2 \cdot 47$ & $3 \cdot 32$ & $4 \cdot 49$ & $0 \cdot 239$ & $15 \cdot 4^{8}$ & $23 \cdot 30$ & $20 \cdot 84$ & $16 \cdot 63^{*}$ & $-0 \cdot 66$ \\
\hline
\end{tabular}

Footnotes as in Table I

\section{Discussion}

In this study, as in our previous study on angle-closure glaucoma, careful matching of the subjects for age, sex, and refraction was considered essential, as these factors can affect the ocular dimensions measured (see Tomlinson and Leighton, 1973). In none of the comparisons of the groups was there a significant difference for age or refraction (see Tables I to III).

Some criticism may be levelled at the inclusion, in the samples of glaucoma relatives, of subjects who were not related to the patients in the index groups. It was not possible to see 
the index patient of every glaucoma relative as some were excluded because of death, removal from the area, or operations which rendered them unsuitable for the measurement of ocular dimensions.

For the index sample, the results of this study agree well with the findings of other workers. Anterior chamber depth and lens thickness were found to be significantly shallower and greater, respectively, in open-angle glaucoma than in the normal (see Törnquist and Brodén (1958) and Storey and Phillips (1971)).

No previous findings appear to be available on the ocular dimensions of first-degree relatives of patients with open-angle glaucoma. In the relatives the depth of anterior chamber and lens thickness differed from the normal in the siblings but not in the offspring. The offspring showed one difference from the normal, i.e. in the diameter of the cornea; no explanation can be offered for this and, though significant, it may be due to chance, i.e. a spuriously "significant" result may occasionally be found.

The finding that the index patients and siblings each showed a similar deviation from the normal with regard to anterior chamber depth and lens thickness, as well as a consistent lack of significant differences from the controls in the other dimensions considered, illustrates their similarity. This suggests that the ocular dimensions which we have considered singly are not important in the aetiology of open-angle glaucoma, although heredity may still be an important factor. The consideration of a combination of dimensions, e.g. in the ratio of axial length of eyeball to diameter of the cornea, revealed a significantly larger ratio in the patients with open-angle glaucoma than in their siblings (a lack of matching of sex in four of the eight pairings is however admitted-see above). This indicates a relatively large ocular volume combined with a relatively small circumference of filtration angle available for the escape of aqueous humour from the eyes with open-angle glaucoma. In respect of this ratio neither cases nor siblings of cases differed significantly from the controls; it may be, however, that unaffected siblings are superior as "controls" to randomly selected controls. This finding suggests that a carefully controlled comparison of patients and their unaffected siblings should be undertaken. Only then perhaps will the role of heredity in open-angle glaucoma be clearly defined.

It seems, on the one hand, that a similarity in the ocular dimensions of patients with open-angle glaucoma and their unaffected siblings may indicate that the ocular dimensions we have considered are unimportant in the aetiology of open-angle glaucoma. On the other hand, the small discrepancies which exist may be the basis for an interplay of several attributes which, if present in varying but collectively optimum amounts, may result in clinical open-angle glaucoma. For example cup/disc ratio is known to be genetically determined (Armaly, I967), and if relatively large, as it would be in large eyeballs (Tomlinson and Phillips, I969), may well be an important prerequisite for the development of open-angle glaucoma. Field defects may be the more likely to occur, however, if the blood pressure is marginally raised though not amounting to clinical hypertension (Leighton and Phillips, 1972), because atheromatous disease of the vessels which supply the optic disc may produce "micro-infarcts".

Some of the attributes we have mentioned are probably genetically determined, although environmental factors may also exist. A random combination of these genetic and environmental attributes in varying proportions would result in open-angle glaucoma; the importance of each attribute will vary when one affected patient is compared to another. Axial length of eyeball is an example of an important variable: i.e. small size of eyeball is related to a high applanation tension and large size of eyeball to a lower applanation tension (Leighton and Tomlinson, I973). When, after the summation of these attributes, 
a composite threshold is exceeded, the disease becomes manifest. Such a multifactorial aetiology would perhaps explain the very variable and generally low prevalence of openangle glaucoma in the relatives of affected patients, as all the attributes necessary for the development of the condition would only occasionally be present in a sufficient degree for open-angle glaucoma to become manifest.

\section{Summary}

A study of certain ocular dimensions in index patients with open-angle glaucoma and in their \& first-degree relatives (siblings and offspring) is described. The value obtained for each dimension in each index patient or relative was compared with the corresponding value obtained for a normal subject of similar age, sex, and refractive error. Two dimensions $\bar{\omega}$ were found to differ significantly from the normal in the index patients and their siblings but not in the offspring; these were anterior chamber depth and lens thickness. The possible means of genetic transmission for these dimensions is considered and related to the suggested modes of inheritance for open-angle glaucoma.

\section{References}

armaly, m. F. (1967) Arch. Ophthal. (Chicago), 78, 35

melmarcelle, y., Collignon-Brach, J., and luyckx-Bacus, J. (i969) Bull. Soc. belge Ophtal., I52, 447

diaz-dominguez, D. (I96I) Ann. Oculist. (Paris), 194, 597

(1966) Arch. port. Oftal., 18, 13

françois, J. (1966) Amer. 7. Ophthal., 6r, 652

——— and HEINTZ-DE BREE, c. (I966) Ibid., 62, I067

- - - , and Tripathi, R. C. (I966) Ibid., 62, 844

-

LEighton, D. A., and Phillips, c. I. (i972) Brit. 7. Ophthal., 56, 447 - and tomlinson, A. (I973) Ibid., 57, 499

LOWE, R. F. (I970) Ibid., 54, II 7

Miller, S. J. H., and PATERSON, G. (I962) Ibid., 46, $5^{\mathrm{I}} 3$

PERKins, E. s., and JAy, B. s. (I960) Trans. ophthal. Soc. U.K., 8o, I 53

podos, s. m., Becker, в., and morton, w. R. (1966) Amer. 7. Ophthal., 62, io39

rosengren, B. (1950) Arch. Ophthal. (Chicago), 44, 523

sIEGEL, s. (I956) "Non-parametric Statistics for the Behavioural Sciences", p. 75.

New York

SMITH, PRIESTLEy (I883) Trans. ophthal. Soc. U.K., 3, 79

StOREy, J. K., and Phillips, C. I. (I97I) Brit. 7. physiol. Optics, 26, 228

tomlinson, A., and leighton, D. A. (i972) Brit. 7. Ophthal., 56, 97

(1973) Ibid., 57, 475

and PHillips, c. I. (1969) Ibid., 53, 765

TÖRNQUIST, R. ( 1956) Ibid., 40, 42 I

and Brodén, G. (1958) Acta ophthal. (Kbh.), 36, 309

waArdenburg, P. J. (1949) Ned. T. Geneesk., 93, 3603

weekers, r., lavergne, G., and prijot, e. (i958) Ann. Oculist. (Paris), r9i, 26

Wilkie, J., Drance, s. m., and schulzer, m. (ig69) Amer. F. Ophthal., 68, 78 